Please do not remove this page

RMIT

UNIVERSITY

\title{
Academic reference librarians prepare for change: An Australian case study
}

Leong, Julia

https://researchrepository.rmit.edu.au/esploro/outputs/9921858063101341/filesAndLinks?institution=61RMIT_INST\&index=null

Leong, J. (2008). Academic reference librarians prepare for change: An Australian case study. Library Management, 29(1/2), 77-86. https://doi.org/10.1108/01435120810844667

Document Version: Submitted Version

Published Version: https://doi.org/10.1108/01435120810844667

Repository homepage: https://researchrepository.rmit.edu.au

(c) Emerald Group Publishing Limited

Downloaded On 2023/04/27 01:37:25 +1000

Please do not remove this page 


\title{
Academic reference librarians prepare for change: an Australian case study
}

Julia Leong

\begin{abstract}
Purpose - The study aimed to identify strategies to enhance change readiness and professional competence in academic reference librarians in a time of organizational change and challenge.

Methodology/Approach - The author, as departmental head, was able to influence strategies taken and to directly observe and record processes and outcomes. Staff also participated in two surveys to establish and trace competence. Motivation to deal proactively with the changing environment was built through good communication and looking at likely future scenarios. Required competencies were established, skills assessed, goals set for professional development, and progress assessed. Staff participated in determining directions and took responsibility for implementing agreed actions.
\end{abstract}

Findings - Reference staff responded positively to enhanced opportunities to influence directions. They willingly took responsibility, developed new skills for a changing environment, and demonstrated effectiveness in new ways. Positive outcomes included recognition through a national award, successful grant applications and project work, and positive attitudes shown by staff at a time of organizational restructuring and downsizing.

Practical implications - Reference staff capability to provide innovative services and to adapt to changing expectations and opportunities is enhanced by participation in management of library directions and through staff development.

Originality - This case study offers insight into practical and inexpensive approaches to enhancing reference librarian change readiness and competence.

\section{Article Type}

Case study

\section{Keywords}

Change management, Reference services, Academic libraries, Staff development 


\section{Introduction}

Academic reference librarians face a challenging work environment where change is driven by technological innovation, growing client expectations, shifts in government policies and financial pressures. To provide effective services and products demands a willingness to adapt to these realities (Bryson, 2006, pp. 14-15). Many organizational change efforts fail (Sims, 2002, p. 1) and it is vital to direct the change process in order to maximize its effectiveness. Enhancing skill levels and building change readiness empowers staff to provide innovative services while maintaining and strengthening their employment prospects and job satisfaction.

The academic reference librarians at the University of New England (UNE), New South Wales, Australia have been deliberately preparing for the future since 2000. In 1999, a joint information technology/library helpdesk was disbanded. This was followed by a reduction in staffing levels and the redeployment of staff to new positions. The result was a renamed department, a new departmental head and a mix of old and new personnel. This case study tracks how staff were involved in managing change over the seven-year life of the Access Services Department.

UNE is a regional university with a high proportion of its students studying from a distance. In 2006, there were 17,854 students, of whom 13,309 studied by distance. The on-campus student cohort is small. There were 3,558 on-campus students in 2006. Additionally, there were 987 students at locations other than Armidale. As many students choose to study part-time, the effective full-time student load was only 9,210.

In 2000, staff were somewhat demoralized by the perceived failure of the joint help desk. The first priority was to refocus and re-energize departmental personnel. To cope with a changing environment, it was necessary to rebuild staff confidence and competence through the introduction of a participatory management style and investment in staff development (Leong, 2005). Failed change is often a result of a failure to involve the staff "whose support is essential to success" (Sims and Sims, 2002, p. 48).

\section{Methodology}

This case study tracks how academic reference librarians at the University of New England (UNE), New South Wales, Australia have prepared for change during the period from 2000 until January 2007. It reviews the steps involved in managing change, the approaches that were taken and how strategies impacted outcomes. The author, as departmental head, was able to influence the strategies taken and to directly observe and record processes and outcomes and this was the primary methodology of the study. Change management literature was studied and applied to strategies undertaken. Staff also participated in two internal surveys to establish and trace competence. The survey instrument was useful for its purpose within the organization, but has not been polished or validated. As the sample was only nine staff, the survey results are not considered to 
be of broad interest, but were used in combination with other information to monitor effectiveness of strategies taken.

\section{Building change readiness}

Before change plans are developed, it is necessary to create readiness among staff (Clarke, 1994, p. 94). This requires more than giving logical reasons for change: it is necessary to present "an emotionally compelling case" (Kotter, 2005, p. 3). If a vision for change is presented without evidence that the status quo is no longer viable, people are unlikely to engage with proposed changes (Zigarmi and Hoekstra, 2007, p. 231). This engagement is crucial for organizational survival. As Ronald R. Sims (2002, p. 1) asserts, organizations must stay ahead of their evolving environment if they are to succeed.

This assertion is particularly relevant to the situation at the University of New England between 2000 and 2007. The institution faced a legacy of debt from an earlier round of restructuring and was experiencing difficulties in maintaining enrolment levels. As a small regional university, UNE found it difficult to compete in the changed Australian higher education environment. In an explicit attempt to build change readiness, Professor Ingrid Moses, the Vice Chancellor at the time, arranged a series of University forums. She spoke openly at these regarding the threats the University faced and the need for change. This message was also conveyed to University staff by other senior executives including the University Librarian.

Belief in the old ways of doing things can be strong and it may be necessary to destabilize people to promote openness to change (Clarke, 1994, p. 148). Smith (2005, p. 409) sees sensitizing organizations and individuals to the need for change as a more productive and less stressful approach. This was necessary at the University as blind commitment to the old order was no longer effective. Reference librarians' change readiness was probably relatively high as staff were already somewhat disturbed by recent events. Clarke (1994, p. 178) states that readiness for change exists when the security level is neither very high nor very low. Those who are insecure resist change (Clarke, 1994, p. 178) and it was important to proceed cautiously and to work to involve staff in setting directions. As Clarke (1994, pp. 7, 31) points out, change is a constant process and increased complexity makes it impossible for top management to clarify directions to a point where staff can operate without ambiguity. To promote constant improvement and responsiveness to the environment in which we work requires a balancing act between providing certainty to allow smooth functioning and maintaining a level of ambiguity to promote flexibility and openness to new ways of working (Kast and Rosenzweig, 1979, pp. 563-565).

Empowering staff to shape responses to the changing environment is vital. Kennedy (1985, p. 329) stresses that we can only achieve "nontrivial things" if we include people in the process from the start. He claims that change will not occur without an "actionable consensus” (Kennedy, 1985, p. 330). Zigarmi and Hoekstra (2007, p. 225) state that increasing the "level of influence and involvement" of those who are expected to change 
is the key to initiating, implementing and sustaining change. Sims (2002, p. 3) also sees maximizing employee involvement as essential. Reference staff at UNE were involved in setting directions from the beginning of the newly formed department. In early 2000, planning meetings were held at which the group agreed values and issues for the immediate future. In addition to ongoing meetings and conversations, staff worked together to determine operational plans. These operational plans flowed through to each individual's personal goals and performance assessments. This participative management process promoted commitment and encouraged staff to take responsibility for outcomes and innovation. Continued improvements occurred at the same time as the department built stability and cohesiveness.

Bryson (2006, p. 26) identifies strategic and scenario planning as two tools which help organizations to understand drivers of change and to develop change readiness. In discussing the value of scenario planning, Bryson (2006, p. 43) identified several benefits which aligned closely with my aims when the Department held our 2004/5 planning meetings which included an informal approach to looking at future scenarios. Scenario planning helps one to consider complex situations, to free up old mindsets, to avoid undervaluing what one does not understand, and to identify early warning signs of new futures (Bryson, 2006, p. 43). Staff were predominantly aged between 40 and 55 and wished to maintain employability and high competence rather than to plateau and wait for retirement. There was talk that traditional reference staff work would decrease as tools such as federated searching could make the information search process less complex. We identified likely directions in the university information environment and how we might equip ourselves to be integral to that environment. This included developing knowledge and capabilities in areas such as federated searching, open URL resolvers and institutional repositories.

\section{Skilling for new scenarios}

\section{Determining needed competencies}

Cohn and Kelsey (2005, p. 14-15) give seven reasons in support of developing a list of competencies for librarians. Included are: their usefulness in helping the library to respond to changing client needs and expectations; their value in helping staff understand what is expected of them; and the information they provide for assessing development needs and creating a staff development programme. At UNE a thorough study was undertaken to strengthen our understanding of the competencies which would equip staff in our reference department to operate in a changing environment. We had ideas from our environmental scans and built on these with a literature review, information from position descriptions, work done in other libraries, policy statements from our professional association, and a scan of training course content.

The literature review focused on skills seen as key for performance in a changing environment. Many of these related to an ability to deal well with technological change and with effective communication in a range of settings. Kong (1996, p. 19) identified a flexible attitude toward technology, tolerance for rapid technological change, creativity, communication skills, public relations savvy, and an ability to relate to adverse clientele 
as critical competencies. Paster (2004, p. 42) suggested Web skills, knowledge of Internet communications, teaching skills and digital reference. Peacock (2001, p. 39) identified skills which are of particular relevance to our faculty librarians. These were: an ability to engage in educational debate and decision-making; ability to influence policy; skill in forging strategic alliances; and diplomacy. Other important skills identified were project management skills (Leong, 2001, p. 91) and the ability to handle diversity (Watstein, 2003, p. 37).

To the literature review was added useful work done in other libraries. The University of New England Library participates in an association based on its neighbouring state. The Queensland University Libraries Office of Cooperation (QULOC) includes Queensland university libraries, the State Library of Queensland, Charles Darwin University Library in the Northern Territory and the libraries of two northern New South Wales universities (Southern Cross University and the University of New England). QULOC has a number of effective working groups including the Staffing Issues Working Party which allows for active sharing of information. The Queensland University of Technology (QUT) Library had developed written specifications of reference librarian competencies and these had been adapted by the University of Southern Queensland. These documents proved to be helpful in preparing our own version of competencies required of those doing reference work.

The reference department had responsibility not only for reference work, but also for information literacy, including Endnote bibliographic database classes and troubleshooting, selection work including electronic database assessment, collection assessment and liaison with faculty. To provide for this broad scope of work, competencies were developed in addition to the reference competencies (known at UNE as information desk competencies). The additional documents were generic competencies, faculty librarian competencies and competencies for the work done by other staff in addition to strictly reference work.

First drafts of the competency documents were largely based on the literature review and the QULOC documents. In refining the draft reference librarian competency documents, ideas were gained from QUT's training topic outline for their liaison (faculty) librarians. Supplementary concepts were added from several sources. One source was our position descriptions which were quite detailed. Position descriptions from job advertisements could also be analyzed, but this was not done in the UNE work. To check for other ideas, the Australian Library and Information Association professional guidelines were considered and a scan was done of paraprofessional training package titles for Museum and Library/Information Services. One of the challenging questions was how much to include in competencies listed for staff and how much to assume as a given. It is not sensible or practical to list all topics covered in a professional qualification and yet many are vital to performance. Some such competencies were included, such as "reference interview/neutral questioning skills”, but most in the reference competencies were more job specific such as knowledge of authentication systems, awareness of document delivery services and knowledge of emergency and evacuation procedures. The Generic Competencies document did include a number of competencies typically included in 
position descriptions. These included time management, problem-solving abilities, knowledge of occupational health and safety requirements and institutional policies. Other concepts in the Generic Competencies document came from the literature review. Examples are the individual's contribution to workplace learning environment, diplomacy and marketing. The latter two were identified by staff as difficult to interpret and needing to be more clearly described. In addition to identifying competencies, the documents suggest ways these competencies can be obtained. Examples are Web pages giving information, training courses, or instruction by nominated staff experts.

\section{Assessing current skill levels}

After determining the competencies needed, a Web survey was created and staff selfassessed in June 2005 on a 5 point scale. To promote consistency in the way staff rated themselves, the following informal descriptions of the scale were provided.

1. Very poor to zero competence or knowledge

2. Some competence or knowledge, but not enough to jump into action quickly and confidently

3. Basic competence or knowledge adequate to do the job, but not good enough to claim to be an expert

4. Strong competence or knowledge, a very satisfactory level to reach for most areas

5. High competence or knowledge, a genuine expert.

The department comprised 12 staff in June 2005 and all completed the survey. In June 2006, some temporary staffing arrangements were in place and only the 10 staff, who had completed the June 2005 survey, were invited to complete the repeated survey. One staff member, who was shortly to retire, did not do so, leaving a small sample of nine staff who completed both surveys.

In June 2005, identified strengths were core reference and faculty librarian work and, pleasingly, a "flexible attitude to technology" for which the average rating was four out of five. Staff also rated their "tolerance for change" strongly at 3.89. Areas of some weakness were generic skills in leadership, marketing and influencing others, use of our latest equipment, and software skills (such as PowerPoint). Those not responsible for Web design, provision of Web resources suitable for disabled users, and special collections also rated themselves lowly in those areas.

\section{Developing skills}

Setting goals for staff development is an integral part of continuous improvement processes (Reed and Avery, 2001, p. 34). Staff development goals for reference staff at UNE are set in several ways. Once the annual operational plan is agreed, individual staff members formulate their goals for the year and identify training needs. These goals and training needs are then discussed and agreed with the supervisor. Staff are encouraged to include goals and development ideas which flow from their career aspirations as well as those needed for work specific responsibilities. In planning training sessions, information 
is gathered from the goal setting exercise and from direct input from staff and supervisors. The UNE work in determining competencies needed and staff self-assessment against those competencies was an additional source of information in planning staff development. The Department's Staff Development Plan 2005-2006 was largely based on findings.

Reed and Avery (2001) raise a number of pertinent questions for setting development goals. Examples of these are looking at what is feasible financially, considering current staff skills and taking into account organizational culture. They also suggest recognizing that the aim is not learning new skills, but the potentially uncomfortable process of changing behaviour and attitudes (Reed and Avery, 2001, p. 36). This need to focus on more than skill sets is highly relevant when seeking to equip staff for a changing environment. What is effective in one library may not be the best solution for another. The staff development of UNE reference librarians, which is the focus of this article, was that of a predominantly mature experienced group of librarians who had already availed themselves of many of the standard organizational development courses. Todaro and Smith (2006, pp. 91-92) affirm the value of training workshops offering "standard chunks of information", but point out that they do not offer adequate diversity to meet all needs. The situation at UNE confirmed this point. A number of the identified development needs for UNE reference librarians were not available in local training courses.

Financial considerations are a significant factor for UNE as library specific training courses and workshops are not offered locally and require travel to larger cities. Travel to the closest state capitals, Sydney and Brisbane, is expensive by air and requires approximately six hours driving time by road. Where courses are particularly relevant to current needs, such as a course in strategic influencing run in Sydney in 2005, staff attend. To meet our training needs requires a mix of additional strategies. Some staff have completed quite extensive leadership or supervisor training programmes offered by UNE. We have also supported a staff member studying for a Graduate Certificate in Higher Education. To increase staff awareness of the importance of marketing, a UNE lecturer specializing in services marketing generously provided an introduction to this area for staff. We have continued to run in-house and vendor sessions on practical topics such as new equipment, individual databases and federated searching.

Jurow (2001, p. 8) mentions adults' need for personal discovery in the learning process. This is well developed by Boyatzis (2002) who notes that the worldwide workforce is aging and who reports on longitudinal studies at the Weatherhead School of Management of Case Western Reserve University which have shown a self-directed learning process is effective in improving the complex set of competencies required for outstanding performance in management and the professions. At UNE we have utilized two approaches which meet this need for personal discovery in the learning process. Many of the staff agreed to take on individual study projects. The work on determining competencies needed was one of these projects. Other topics have included blogs, rss, podcasting, open access journals and a targeted marketing project. Participation was expected, but was not compulsory. Most staff participated, but the level of effort varied depending on their enthusiasm and the time they had available. Staff determined their 
approach and how they would present results. This varied from leading a small group discussion on how the individual is impacted by change to several presentations to library staff on new technologies. The commitment involved in preparing such a presentation results in much deeper learning then would result from attending a workshop. It has also had the benefit of building a team of mini experts and staff have commented positively on the value of knowing to whom they can refer for help or advice.

Another approach to equipping staff for a changing environment has been to encourage "play" with technology. The aim is to gain understanding in a non-threatening environment without strong time pressures. One example of this is encouraging staff with low-level PowerPoint skills to develop a simple presentation when giving information to other staff. Staff seconded temporarily from another section used blogs to track their learning experiences thus learning a new technology skill and gaining practice in self reflection. In the 2006 -2007 planning round, a Yahoo group was established and much of the planning discussion was held online in the group (Leong, 2006). Yahoo polls were used to assess the effectiveness of this and responses from staff, rating their competence in use of an online group, showed a jump in competence as a result of this work-related learning experience.

\section{Checking progress in skills development}

Approaches taken at UNE to prepare reference staff for a constantly changing environment illustrate a low-cost mix of learning approaches. As Sims (2002, p. 2) points out, no single approach to managing change will suffice in all circumstances, but the UNE strategies have been effective for local circumstances. The June 2006 survey of staff competence showed gains in confidence over the base survey in June 2005. As all staff involved were continuing staff, this was reassuring. 30 of the 31 questions relating to reference and inquiry desk work showed improved self-ratings by staff. As the average was sound in the previous year it is likely that improvements primarily reflected newer staff gaining confidence. These were the non-faculty librarians and their confidence on questions specific to their other work showed 21 of 22 questions rating higher with substantial confidence gains. The questions specific to faculty librarians showed much less movement with 16 the same, 15 up and nine down. Of particular interest were the generic competencies as a number of these had been targeted for development effort. Of 21 questions, staff rated their confidence more highly on 19. Average ratings on leadership, diplomacy, marketing and the ability to influence others improved by $.22-.55$ on a scale of 1-5. "Tolerance for change" moved from 3.89 to 4.11 and "flexible attitude to technology" improved from 4 to 4.11 .

\section{Positive outcomes}

As can be seen from the staff self ratings of competency, reference staff at UNE are positive about change, technology, and their competence. The confidence is in itself a valuable asset. The Library has added innovative services and new technology in recent years and will continue to do so. Federated searching and a URL resolver have resulted in animated discussions as to the best way to utilize this technology in training and on web 
pages. An institutional repository will be launched in 2007 and reference staff will be involved in marketing and client liaison.

In 2007, reference staff will be planning and implementing a single service desk for the Library. In preparation for this, reference, lending and document delivery areas of the library merged into the Information Services Department in February 2007. Such a highimpact change tests staff attitudes. However, the constructive and calm responses of reference staff have been exemplary. This, more than anything else, has shown that their strong self-rating regarding change tolerance is indeed accurate.

Staff interest in innovation has also increased. To encourage innovation, government and institutional policies are to move some recurrent funding to competitive and project based funding. The reference department has responded well to this change. Over the past few years, several staff have been involved in funded projects to include generic attributes in academic units of study with our interest being in developing information literacy capabilities. Internal UNE grant funding was received in 2006 for three projects led by staff in the Department and an additional member of staff was involved in contributing to several other teaching development grant projects as a partner. Library led projects were received to develop podcasting, to provide assignment specific pathways to information for assignments in online units, and to redevelop our online information literacy tutorials for postgraduates.

Staff development in the area of marketing has aligned with success in being awarded one of the 2006 Carrick Awards for Australian University Teaching, Citations for Outstanding Contributions to Student Learning. These awards are provided by the Australian Government Department of Education, Science and Training to encourage innovation in teaching. This was awarded to the team who developed and maintained our information literacy web resource, eSKILLS UNE.

\section{Conclusion}

Reference work in academic libraries is demanding and requires adaptation to constant change. At UNE, change readiness was built from the top-down by communicating the need for change openly and repetitively. Staff at UNE have been well equipped to respond positively to change by being involved in determining issues and planning organizational directions. Regular and targeted staff development, utilizing a variety of approaches, has built confidence and competence. Staff have responded positively to the challenges showing enthusiasm for new areas of work and taking innovative approaches to improving service. Participative management empowers staff to take innovative approaches and provide high quality services. People need time to adjust to change (Clarke, 1994, p. 1). The fact that this process has been spread out over several years was almost certainly one reason for the success of the change management process. 


\section{References}

Boyatzis, R. E. (2002), "Unleashing the power of self-directed learning", in R. R. Sims (Ed.), Changing the Way We Manage Change, Quorum Books, Westport, Conn., pp. 13-32.

Bryson, J. (2006), Managing Information Services: A Transformational Approach, Ashgate, Aldershot, Hampshire.

Clarke, L. (1994), The Essence of Change, Prentice-Hall, New York.

Cohn, J. M. and Kelsey, A. L. (2005), Staffing the Modern Library: a How-To-Do-It Manual, Neal-Schuman Publishers, New York.

Jurow, S. (2001), "How people learn: applying adult learning theory and learning styles models to training sessions", in E. F. Avery, T. Dahlin and D. A. Carver (Ed.), Staff Development: A Practical Guide, American Library Association, Chicago, pp. 6-9.

Kast, F. E. and Rosenzweig, J. R. (1979), Organization and Management: A Systems and Contingency Approach, McGraw-Hill, Tokyo.

Kennedy, A. A. (1985), "Ruminations on change: the incredible value of human beings in getting things done", in W. G. Bennis, K. D. Benne and R. Chin (Ed.), The Planning of Change, Holt, Rinehart \& Winston, New York, pp. 325-335.

Kong, L. M. (1996), "Academic reference librarians: under the microscope", The Reference Librarian, Vol. 54, pp. 21-27.

Kotter, J. P. (2005), "Change leadership", Leadership Excellence, Vol. 22, No.12, pp. 3-4.

Leong, J. (2001), "A case study in collaborative information literacy web development work", in Revelling in Reference 2001: RAISS - Reference and Information Services Section Symposium Proceedings: 12-14 October 2001, Australian Library and Information Association, Kingston, ACT, pp. 87-98.

Leong, J. (2005), "Participation or parody: leadership for the future", neXt 2005: 13th ALIA National Library and Information Technicians Conference, Sydney Convention \& Exhibition Centre, 6th-9th September 2005, Available http://eprints.alia.org.au/archive/00000059/.

Leong, J. (2006), "Library planning using online group discussions", inCite, Vol. 27, No. 12, pp. 8, Available http://www.alia.org.au/publishing/incite/2006/12/print.html?ID=139.

Paster, L. R. (2004), "Current issues in staff development", in J. Simmons-Welburn and B. McNeil (Ed.), Human Resource Management in Today's Academic Library: Meeting Challenges and Creating Opportunities, Libraries Unlimited, Westport, Conn., pp. 37-46.

Peacock, J. (2001), "Teaching skills for teaching librarians: postcards from the edge of the educational paradigm", AARL: Australian Academic \& Research Libraries, Vol. 32, No.1, pp. 26-42.

Reed, N. L. and Avery, E. F. (2001), "How to set goals", in E. F. Avery, T. Dahlin and D. A. Carver (Ed.), Staff Development: A Practical Guide, American Library Association, Chicago, pp. 34-37.

Sims, R. R. (2002), "General introduction and overview of the book", in R. R. Sims (Ed.), Changing the Way We Manage Change, Quorum Books, Westport, Conn., pp. 1-9. 
Sims, S. J. and Sims, R. R. (2002), "Employee involvement is still the key to successfully managing change", in R. R. Sims (Ed.), Changing the Way We Manage Change, Quorum Books, Westport, Conn., pp. 33-54.

Smith, I. (2005), "Achieving readiness for organisational change", Library Management, Vol. 26, No.6/7, pp. 408-412.

Todaro, J. and Smith, M. L. (2006), Training Library Staff and Volunteers to Provide Extraordinary Customer Service, Neal-Schuman Publishers, New York.

Watstein, S. B. (2003), "Scenario planning for the future of reference: five white papers posit the future and raise the bar for us all", Reference Services Review, Vol. 31, No.1, pp. 36-38.

Zigarmi, P. and Hoekstra, J. (2007), "Leading change", Leading at a Higher Level: Blanchard on Leadership and Creating High Performing Organizations, Pearson Prentice Hall, Upper Saddle River, N.J., pp. 223-249. 